\title{
Modern Concepts of Ethiological Pathogenesis and Treatment of Endometrial Carcinoma, Research Literature Review
}

\author{
Todor Dimitrov ${ }^{1}$, Grigor Gorchev ${ }^{2}$, Slavcho Tomov $^{3}$ \\ UMHAT “Dr. G.Stranski” Ltd.-city of Pleven, Clinic in Oncology Ginecology, Medical University - city of Pleven
}

\begin{abstract}
Endometrial carcinoma is a frequently diagnosed gynecologic neoplasm on a global scale. Most often it affects females between 50 and 70 years of age. The reasons for development of this disease are many and various, as obesity is one of the leading among them worldwide. It is a chronic, poly-ethiologic disease resulting from the interaction of endogenous and exogenous factors, which is characterized by excessive accumulation of fat in the body due to an increase in the size and/or number of fat tissue. Aim: The objective of this paper is to perform a review of the research literature on the issue of endometrial cancer and changes in the immune systems in these patients.
\end{abstract}

Keywords: endometrial cancer, immune system.

\section{Introduction}

Epidemiology of endometrial carcinoma

Endometrial carcinoma is a frequently diagnosed gynecologic neoplasm on a global scale. Most often it affects females between 50 and 70 years of age. In one third of the patients the disease occurs at a younger age as well. [1].
Every year the US National Cancer Institute registers about 50,000 new cases of endometrial carcinoma, as 8,000 women per annum die with this diagnosis. [2]

A gradual increase in incidence is observed worldwide, Figure 1. According to the latest data from the National Cancer Registry for the year 2012, the registered cases of cervical cancer in Bulgaria are 28.5 per 100,000 women, while the average for Europe are 13.4 per 100,000 women. [3]

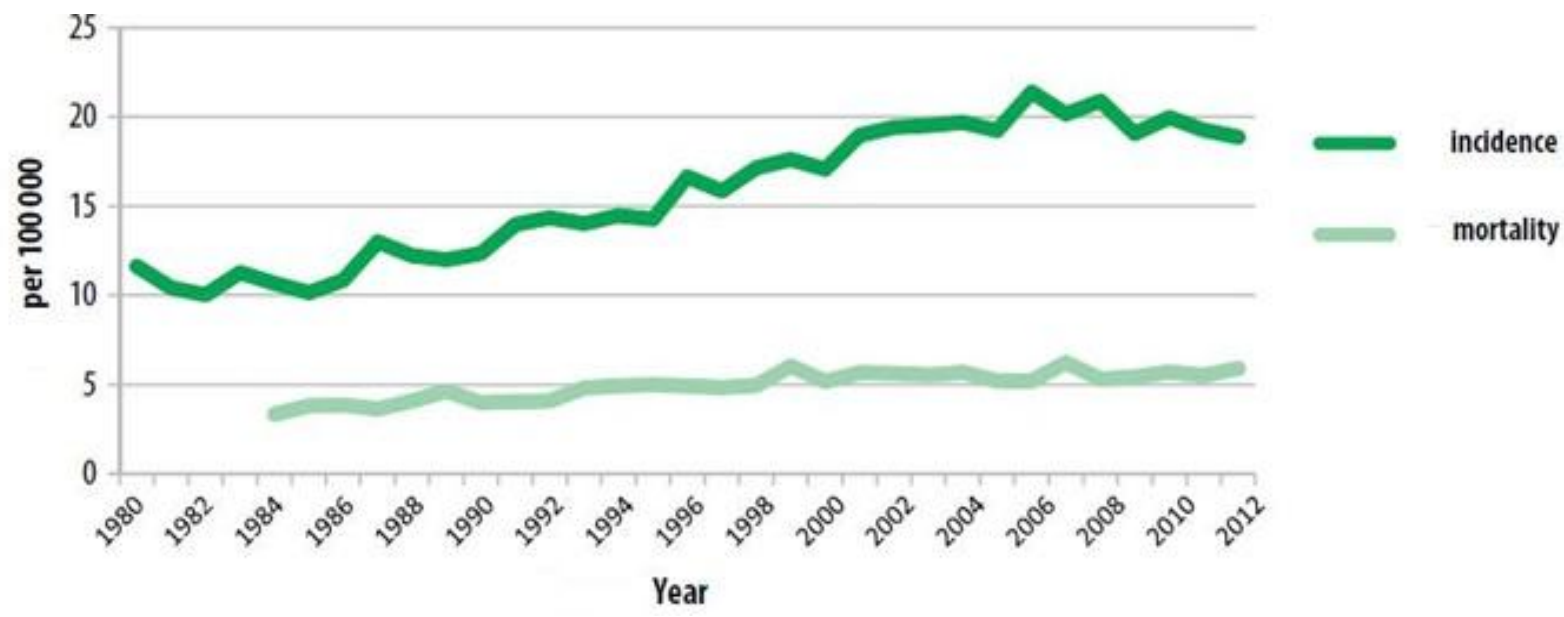

Figure 1: Standardized incidence and mortality (global standard of 100,000) of cervical carcinoma per year of diagnosis.[4]

According to Bulgarian National Cancer Registry the incidence of endometrial and cervical carcinoma is greater in females between 45 and 74 of age, Figure 2. [4] 
International Journal of Science and Research (IJSR)

ISSN (Online): 2319-7064

Index Copernicus Value (2013): 6.14 | Impact Factor (2015): 6.391

\section{FEMALES $60-74$ (6004 CASES)}

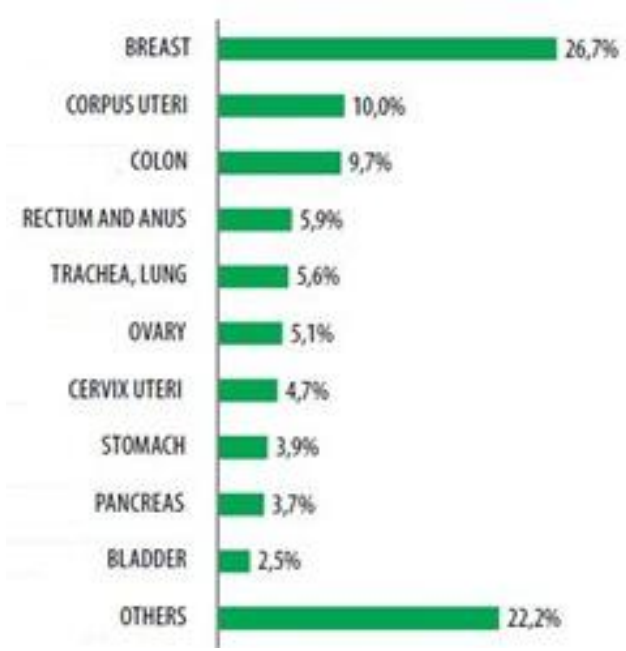

Figure 2: Percentage distribution of the most common malignancies in females in two age groups in Bulgaria, 2012. [4]

The reasons for the above are related to the development of modern diagnostics, as well as to lifestyle and urbanization. Poor eating habits - overeating, consumption of foods suppressing the oxidative processes, endocrine disorders, hypokinesia (reduced physical activity), obesity, etc., all form a prerequisite for the growing incidence of the disease [5], [6], [7], [8 ], [9], [10]. Malignant neoplasms of the uterus mainly affect the endometrium, whereas malignant tumors originating from the myometrium are considerably less common.

\section{Overweight as a leading pathophysiological factor for endometrial carcinoma}

The reasons for development of this disease are many and various, as obesity is one of the leading among them worldwide. It is a chronic, poly-ethiologic disease resulting from the interaction of endogenous and exogenous factors, which is characterized by excessive accumulation of fat in the body due to an increase in the size and/or number of fat tissue. Nowadays overweight and obesity are a global problem with expressed co-morbidity and high mortality rate. Bulgaria is ranked sixth in the world in terms of obesity, as obese women are $35 \%$, men $-25 \%$, and children and adolescents between $10-12 \%$. In order to determine the degree of obesity a single method called "Body Mass Index (BMI) is used, which was described in 1896 by Lambert Adolphe Jacques Quetelet. The index is the ratio between weight in kilograms and height in meters squared (BMI = body mass/height, $\mathrm{kg} / \mathrm{m} 2$ ). According to the World Health Organization the degree of obesity is precisely determined by the classification of body mass index (BMI), Table 1, Figure 3.

Table 1: Obesity classification by body mass index

\begin{tabular}{|c|c|c|c|c|c|c|}
\hline Body mass index $($ BMI $)$ & $<18.5$ & $18.5-24.9$ & $25.0-29.9$ & $30.0-34.9$ & $35.0-39.9$ & $\geq 40.0$ \\
\hline Classification & Underweight & Normal weight & Overweight & Obesity class I & Obesity class II & Obesity class III \\
\hline
\end{tabular}

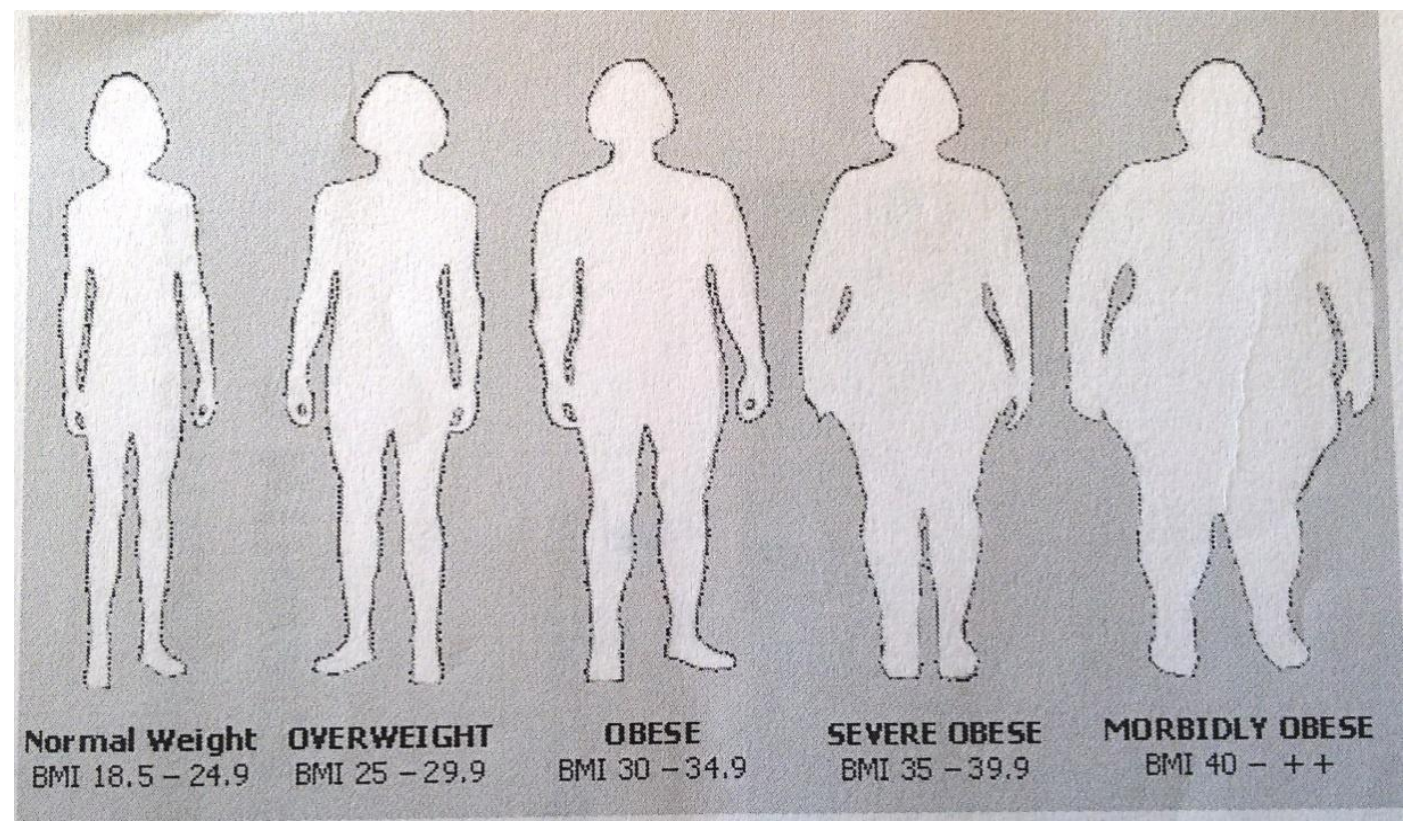

Figure 3: Degree of obesity by body mass index and its impact on the female body

Overweight in females is one of the significant risk factors for predisposition to endometrial cancer - $50 \%$ of the cases. [9], [11], [12].

According to multicentre studies conducted in Europe and the United States (International Agency for Research on Cancer (IARC), World Cancer Research Fund, American Institute for Cancer Research), overweight females (BMI>
$30 \mathrm{~kg} / \mathrm{m} 2$ ) run 3 times higher risk of developing endometrial cancer as compared to women of normal weight.

Several biological mechanisms mediate the link between overweight and endometrial neoplastic risk (cancer risk). In postmenopausal women obesity leads to conversion of androgens, increase in serum bioavailability of estrogens, which are not balanced by progesterone, which in turn

\section{Volume 5 Issue 7, July 2016}

\section{www.ijsr.net}




\section{International Journal of Science and Research (IJSR) \\ ISSN (Online): 2319-7064}

Index Copernicus Value (2013): 6.14 | Impact Factor (2015): 6.391

enhances the mitogenic activity of endometrial cells. [13], [14], [15]. Other important factors that are associated with obesity as a prerequisite for development of endometrial cancer are the so-called called Adipocytokines. They include:

\section{Adiponectin}

It is a specific biological factor secreted by adipose tissue and in low quantity by cardiac myocytes, muscle and endothelial cells. [16], [17], [18].

The function of adiponectin is defined as antiatherogenic, anti-inflammatory and insulin-sensitive. [19].

In contrast to other adipokines, the level of circulation adiponectin has a negative impact - i.e., it reduces obesity, BMI, visceral fat concentration and insulin resistance. [20] A number of studies demonstrate that postmenopausal women have low levels of adiponectin, which favors the development of a number of tumors - breast, colorectal, endometrial carcinoma. [21], [22], [23].

In vitro experiments prove that adiponectin inhibits neoplastic cell proliferation and apoptosis, lowers TNF- $\alpha$ production by macrophages, enhances the production of anti-inflammatory cytokines IL-10 and IL1RA of lymphocytes. [24], [25], [26].

Thus, through the anti-inflammatory and immunomodulatory influence, the anti-cancer effect of adiponectin is attained. Its low level in a number of studies is associated with obesity and increased risk of neoplasm. [21], [27].

\section{Leptin}

This is $16 \mathrm{kDA}$ adipokine and it has a very important role in body weight and the body's energy balance through its influence on food absorption and through stimulating energy expenditure. Its circulation level affects the hypothalamicanorexic neurons and plays a key role on hyperphagia and total BMI. [17], [28], [29].

A strong positive correlation is established between the high level of leptin, overweight, metabolic dysfunction and endometrial carcinoma. [30

There is evidence that leptin enhances cellular neoplastic proliferation in endometrial carcinoma by activating cyclooxygenase 1 (Cox-2).

The high leptin level becomes involved in a vicious circle progesterone deficiency $\rightarrow$ hyperinsulinemia $\rightarrow$ increased endogenous estrogens $\rightarrow$ increased endometrial carcinomatosis risk $\rightarrow$ endometrial cancer in postmenopausal patients, known as the so-called "estrogen hypothesis.

\section{Insulin-like growth factor-1}

The adipose tissue dysfunction in obese individuals plays a key role in the triggering and development of insulin resistance (obesity-linked hyperinsulinemia.)

Insulin and C-peptide are secreted in equimolar amounts, but C-peptide with its longer lifecycle and smaller fluctuation gives a more accurate idea of the production of insulin, which is secreted by the pancreas. A multicentre European prospective study (European Prospective Investigation into Cancer and Nutrition 2013) establishes a strong association between the pre-diagnostic serum concentrations of Cpeptide, insulin-binding growth proteins (IGFBP 1 and IGFB 2), overweight (high BMI) and neoplastic carcinogenic risk. [31] [32] There are several, even though not fully clarified mechanisms, which link etiopathogenetic hyperinsulinemia and endometrial carcinoma:

- Insulin directly stimulates the proliferation of the endometrium;

- Insulin increases IGF1 bioactivity;

- Insulin reduces hepatic secretion and the circulatory level of IGFBP1 and 2, which leads to an increase of androgens and progesterone deficiency, the so-called imbalance of sex hormones in the pre- and postmenopausal period in women. [16], [33], [10], [34], [35]

\section{Adipose Tissue Hypoxia - Oxidative Stress}

Oxidative stress may cause imbalance of cellular metabolism and antioxidant stability of cells. [36] [37] Elevated oxidative stress induces intracellular accumulation of peroxide radicals and is an early indicator of the metabolic syndrome with adipose degeneration of the cells. Oxidative stress leads to dysregulation in the production of adipokines, cytokines and chemokines (Adiponectin, Leptin, Resistin, IL-6, etc.).

The role of oxidative stress has a dual significance, and yet authors agree on the fact that oxidative products (ROS) control tumor proliferation and increase the metastatic potential of tumor cells. [24], [38], [39], [40].

\section{Sex hormones and endometrial carcinoma}

A number of authors examine adipose tissue as an organ secreting various hormones. [6], [41], [11].

Obesity is associated with increased serum concentration of estradiol, estrogen, and reduced serum concentration of testosterone. During the postmenopause period adipocytes transform androstenedione into estrogen via aromatization. Obese females have 10 times higher levels of estrogens as compared to normal weight females. [35], [42], [43].

Kerschaw EE calls adipose tissue "an endocrine organ".[19]

Adipose tissue elevates insulin, IGF-1, which closes the circle $\rightarrow$ increased bioavailability of estradiol $\rightarrow$ reduced testosterone production $\rightarrow$ increased estrogen neoplastic sensitivity and possible neoplastic breast and endometrium proliferation. [44], [45].

Irrespective what the BMI of patients is, every surgical intervention exerts an influence on the immune system.

\section{Immune system and endometrial carcinoma}

When translated from Latin, the word "immunity" means free. Everything that is not accepted by the body as "its own", is regarded as a foreign, undesirable load. The basis for recognition of a foreign body and the subsequent defense from it leans on mechanisms of specific and non-specific immunity, which can act both together and separately.

\section{Volume 5 Issue 7, July 2016




\section{International Journal of Science and Research (IJSR) \\ ISSN (Online): 2319-7064}

Index Copernicus Value (2013): 6.14 | Impact Factor (2015): 6.391

It is well known that nonspecific immunity is genetically conditioned and it does not need a preceding contact with the foreign body. In contrast, the mechanism of specific immunity secures the creation of acquired immunity. [46].

Experimental and clinical studies have demonstrated that surgical trauma entails a change in the immunological response, progressing into the production of proinflammatory cytokines, suppression of cell-mediated immunity and change in programmed cell death, the socalled "apoptosis". [47], [48], [49], [50], [51].

All these unfavorable changes related to the immune system which is being altered not only as a result of surgical stress, but also due to the cancer disease itself, enhance the endeavor of gynecologic oncologists to use such surgical methods that are capable of reducing the frequency of complications, hospital stay and surgical trauma.

\section{High technologies in the treatment of endometrial carcinoma}

High technologies in medicine are increasingly entering surgical practice on a wide scale. Their main objective is to achieve greater precision, reduce pain and complications and improve the quality of life in the postoperative period. [52].

This is attained to the greatest extent by robotized surgery performed with da Vinci surgical system. [53]

Robot-assisted laparoscopic hysterectomy with stage-bystage lymphadenectomy in the treatment of endometrial cancer quickly replaces "open techniques" within a relatively short period after the introduction of the technology in 2005 by a number of surgeries worldwide. [54], [55].

Because of the anatomical and physiological characteristics of extremely obese individuals (BMI $>40 \mathrm{~kg} / \mathrm{m} 2$ ), a number of difficulties are observed in performing surgery on organs located in the pelvis. Overweight is a "bottleneck" for the selection of surgical procedure, since the intra- and postoperative complications are more distinct in these patients. [56], [57].

This is precisely what requires the use of minimally invasive surgical techniques whereby the frequency of intra- and postoperative complications is greatly reduced. In indisputable manner, robotic surgery is establishing itself as state-of-the-art surgical technique in recent years.

The advantages of this innovative method are associated with a better opportunity to review the operative field, to reduce operative accidents due to the greater precision in performing the intervention, to decrease hospital stay and blood loss. [58].

Over the past decade the development of laparoscopic and robotic equipment, as well as the use of immunohistochemical methods to prove micrometastases in lymph nodes located in the so-called "strategic place", have all created an opportunity for individual approach in the treatment of oncological diseases, including of the female reproductive system tumors. The sole objective is to reduce postoperative complications and mortality. [59].

The success of robotic surgery in patients with obesity and endometrial cancer is also reported by Tsvetanova at al. [60] (Dissertation). The survey conducted by the authors does not register any complications related to the surgery and anesthesia in patients with endometrial carcinoma.

\section{Conclusion}

Endometrial carcinoma is one of the leading malignancies among women worldwide, causing relatively high mortality rate. Women with this disease are often overweight, which creates a prerequisite for more frequent complications in both the intra- and post-operative period.

Immune system has proven particularly sensitive to surgical trauma. The currently existing modern high-tech surgical methods, leading among which is the robotic surgical system Da Vinci, find successful application in this patient group. This provides a chance not only for more facile postoperative period, but also for a better quality of life of such patients.

\section{References}

[1] Валерианова 3. Злокачествените заболявания в България, страните от Европейския съюз и Северна Америка. VIII Национален конрес по онкология с международно участие 2011, 10-13 ноември, София. Сборник с резюмета, 42-43.

[2] Dossus L, Rinaldi S, Becker S, Lukanova A, Tjonneland A, Oslen A et al. Obesity, inflammatory markers and endometrial cancer risk: a prospective case-control study. Department of Obstetrics and Gynecology, New York University School of Medicine, 10016 New York, New York, USA, 2014.

[3] http://eco.iarc.fr/EUCAN/.

[4] Валерианова 3., Български национален раков регистър. София, 2014.

[5] National Comprehensive Cancer Network. NCCN Clinical Practice Guidelines in Oncology: Uterine Neoplasms. V. 1. 2013. Accessed at www.nccn.org on July 22, 2013.

[6] Beral V, Bull D \& Reeves G. Endometrial cancer and hormone-replacement therapy in the Million Women Study. Lancet. 2005; 365: 1543-1551.

[7] Bergstrom A, Pisani P, Tenet V, Wolk A, Adami HO. Overweight as an avoidable cause of cancer in Europe. Int J Cancer. 2001; 91: 421-30. (Erratum, Int J Cancer 2001; 92-927)

[8] Mantovani G, Maccio A, Mura L, Massa E, Mudu MC, Mulas $C$ et al. Serum levels of leptin and proinflammatory cytokines in patients with advancedstage cancer at different sites. J Mol Med. 2000; 78:554-561

[9] Cust AE, Allen NE, Rinaldi S, Dossus L, Friedenreich C, Olsen A et al. Serum levels of C-peptide, IGFBP-1 and IGFBP-2 and endometrial cancer risk; results from the European Prospective Investigation into Cancer and Nutrion. Int J Cancer. 2007; 120: 2656-2664. 


\section{International Journal of Science and Research (IJSR) \\ ISSN (Online): 2319-7064}

Index Copernicus Value (2013): 6.14 | Impact Factor (2015): 6.391

[10] Chin J. Proportions of cancer attributable to weight. Adapted from Cancer Council (2009). Position Statement: Overweight, Obesity and Cancer Prevention. Retrieved 9/10/2011 from http://www.cancer.org.au/File/PolicyPublications/Posit ion_statements/PS_Overweight_obesity_and_cancer_p revention June 2008 Updated September 2009.pdf.

[11] Dossus L, Lukanova A, Rinaldi S, Allen N, Cust AE, Becker $\mathrm{S}$ et al. Hormonal, Metabolic and inflammatory profiles and endometrial cancer risk within the EPIC cohort - a factor analysis. American Journal of Epidemiology. 2013; 177(8) 787-799.

[12] Mathew SJ, Haubert D, Krönke M, Leptin M. Looking beyond death: a morphogenetic role for the TNF signaling pathway. Journal of Cell Science. 2009; 122(12): 1939-1946.

[13] Pavelka JC, Ben-Shachar B, Fowler JM et al. Morbid obesity and endometrial cancer: surgical, clinical and pathologic outcomes in surgically managed patients. Gynecol Oncol. 2004; 95: 588-592.

[14] Setiawan VW, Yang HP, Pike MC, McCann SE, Yu H, Xiang YB et al. Type I and II endometrial cancers: have they different risk factors? Department of Preventive Medicine, Keck School of Medicine, University of Southern California, 1450 Biggy St, Rm 1517G, Los Angeles, CA 90033. vsetiawa@usc.edu. 2014.

[15] Schouten LJ, Goldbohm RA, van den Brandt PA. Anthropometry, physical activity and endometrial cancer risk: results from the Netherlands cohort study. International Journal of Gynecological Cancer. 2006; 16(2): 492.

[16] Allen NE, Timothy JK, Dossus L, Rinaldi S, Cust A, Lukanova A et al. Endogenous sex hormones and endometrial cancer risk in women in the European Prospective Investigation into Cancer and Nutrition (EPIC). Endocrine-Related Cancer. 2008; 15: 485-497.

[17] Calee EE, Rodriguez C, Walker-Thurmond K et al. Overweight, obesity and mortality from cancer in a prospectively studied cohort of U.S. adults. N Engl J Med. 2003; 348: 1625-1638.

[18] Chin J. Proportions of cancer attributable to weight. Adapted from Cancer Council (2009). Position Statement: Overweight, Obesity and Cancer Prevention. Retrieved 9/10/2011 from http://www.cancer.org.au/File/PolicyPublications/Posit ion_statements/PS_Overweight_obesity_and_cancer_p revention_June_2008_Updated_September_2009.pdf.

[19] Kershaw EE, Flier Js. Adipose tissue as an endocrine organ. The Journal of Clinical Endocrinology and Metabolism. 2004; 89(6): 2548-2556.

[20] Kaaks R, Lukanova A \& Kurzer MS. Obesity, endogenous hormones and endometrial cancer risk: a synthetic review. Cancer Epidemiology, Biomarkers and Prevention. 2002; 11: 1531-1543.

[21] Patel ST, Mistry T, Brown JE, Digby JE, Adya R, Desai KM et al. A novel role for the adipokine visfatin/pre-B cell colony-enhancing factor 1 in prostate carcinogenesis. Peptides 31. 2010; 51-57.

[22] Eguchi J, Wang X, Yu S, Kershaw EE, Chiu PC, Dushay $\mathrm{J}$ et al. Transcriptional control of adipose lipid handling by IRF4. Cell Metab 2011; 13: 249-259.
[23] Wang T, Rohan TE, Gunter MJ, Hue X, WactawskiWende J, Rajpathak $\mathrm{S}$ et al. A prospective study of inflammation markers and endometrial cancer risk in postmenopausal hormone nonusers. Cancer Epidemiology Biomarkers\&Prevention. www.cebp.aacrjournals.org. 2011.

[24] Arai M, Uchiba M, Komura H, Mizuochi Y, Harada N, Okajima K. Metformin, an antidiabetic agent, suppresses the production of tumor necrosis factor and tissue factor by inhibiting early growth response factor-1 expression in human monocytes in vitro. $\mathrm{J}$ Pharmacol Exp Ther 2010: 334: 206-213.

[25] Arima K, Nasu K, Narahara H, Fujisawa K, Matsui N, Miyakawa I. Effects of lipopolysaccharide and cytokines on production of RANTES by cultured human endometrial stromal cells. Molecular Human Reproduction. 2000; 6: 246-251.

[26] Baglietto L, English DR, Hopper JL, MacInnis RJ, Morris HA, Tilley WD et al. Circulating steroid hormone concentrations in postmenopausal women in relation to body size and composition. Breast Cancer Res Treat. 2009; 115: 171-179.

[27] Perrier S, Darakhshan F \& Hajduch E. IL-1 receptor antagonist in metabolic disease: Dr Jekyll or Mr Hyde? FEBS Letters. 2006; 580: 6289-6294.

[28] Inadera H. The usefulness of circulating adipokine levels for the assessment of obesity-related health problems. International Journal of Medical Sciences. 2008; 5(5): 248-262.

[29] Patel ST, Mistry T, Brown JE, Digby JE, Adya R, Desai KM et al. A novel role for the adipokine visfatin/pre-B cell colony-enhancing factor 1 in prostate carcinogenesis. Peptides 31. 2010; 51-57.

[30] Pfeiffer L, Pfeiffer G. Serum levels of interleukins, growth and anglogenin in patients with endometrial cancer. Journal of Cancer Research and Clinical Oncology. 1997; 123(3): 167-172.

[31] Hotamisligil GS, Murray DL, Choy LN, Spiegelman BM. Tumor necrosis factor alpha inhibits signaling from the insulin receptor. Proc Natl Acad Sci USA. 1994: 4854-4858.

[32] Hosono S, Matsuo K, Hirose $\mathrm{K}$ et al. Weight gain during adulthood and body weight at age 20 are associated with the risk of the endometrial cancer in Japanese women. Journal of Epidemiology. 2012; 21(6): 466-473.

[33] Chen B (2011). Theories of obesity and cancer. Adapted from Roberts DL, Dive C \& Renehan AG (2010). Biological Mehanisms Linking Obesity and Cancer Risk: New Perspectives. Annual Review of Medicine, 61, 301-316.

[34] De Luca C \& Olefsky JM (2008). Inflammation and insulin resistance. FEBS Letters, 582(1), 97-105.

[35] Folkerd E \& Dowsett M. Influence and Sex Hormones on Cancer Progression. Journal of Clinical Oncology, 2010; 28 (26) 4038-4044.

[36] Flavin R, Peluso S, Nguyen PL, Loda M. Fatty acid synthase as a potential therapeutic target in cancer. Future Oncol. 2010; 6: 551-562.

[37] Flegal KM, Carrol MD, Ogden CL et al. Prevalence and trends in obesity among US adults, 1999-2008. JAMA. 2010; 303: 235-241. 


\section{International Journal of Science and Research (IJSR) \\ ISSN (Online): 2319-7064}

Index Copernicus Value (2013): 6.14 | Impact Factor (2015): 6.391

[38] Baiocchi G, Kavanagh JJ, Talpaz M, Wharton JT, Gutterman JU, Kurzrock R. Expression of the macrophage colony-stimulating factor and its receptor in gynecologic malignancies. Cancer. 1991; 67: 990996.

[39] Bernardini MQ, Gien LT, Tipping H, Murphy J, Rosen BP. Surgical outcome of robotic surgery in morbidly obese patient with endometrial cancer compared to laparotomy. Int J Gynecol Cancer. 2012; 22: 76-81.

[40] Dossus L, Lukanova A, Rinaldi S, Allen N, Cust AE, Becker S et al. Hormonal, Metabolic and inflammatory profiles and endometrial cancer risk within the EPIC cohort - a factor analysis. American Journal of Epidemiology. 2013; 177(8) 787-799.

[41] Charnock-Jones DS, Sharkey AM, Rajput-Williams J, Burch D, Schofield JP, Fountain SA. Indentification and localization of alternately spliced mRNA for vascular endothelial growth factor in human uterus and estrogen regulation in endometrial carcinoma cell lines. Biol Reprod. 1993; 48:1120-1128.

[42] Lane D, Robert V, Grondin R, Rancourt C, Piche A. Malignant ascites protect against TRAIL-induced apoptosis by activating the PI3K/Akt in human ovarian carcinoma cells. Int J Cancer. 2007; 121: 1227-1237.

[43] Lau S, Buzaglo K, Vaknin Z, Brin S, Kaufer R, Drummond $\mathrm{N}$ et al. Relationship between body mass index and robotic surgery outcomes of women diagnosed with endometrial cancer. International Journal of Gynecological Cancer. 2011; 21: 4.

[44] Petrelli JM, Calle EE, Rodriguez C, Thun MJ. Body mass index, height and postmenopausal breast cancer mortality in a prospective cohort of US women. Cancer Causes Control. 2002; 13: 325-32.

[45] National Health and Nutrition Examination Survey 1999-2000. Atlanta: Centers for Disease Control and Prevention. 2002. (Accessed April 1, 2003, at http://www.cdc.gov/nchs/about/major/nhanes/NHANE S99_00.htm.).

[46] Камелия Цветанова. Имунна система и анестезия. Медицински журнал „Света Анна,. Том II, 2016, №1, Стр. 49.

[47] Nam EJ, Kim SW, Kim S, Kim JH, Jung YW, Paek JH et al. A case-control study of robotic radical hysterectomy and pelvic lymphadenectomy using 3 robotic arms compared with abdominal radical hysterectomy in cervical cancer. Int J Gynecol Cancer. PubMed. 2010; 20: 1284-9.

[48] Sonnenberg GF, Fouser LA, Artis D. Border patrol: regulation of immunity, inflammation and tissue homeostasis at barrier surfaces by IL-22. Nat Immunol. 2011; 12: 383-390.

[49] Velijovich DS, Paley PJ, Drecher CW et al. Robotic surgery in gynecologic oncology: Program initiation and outcomes after the first year with comparison with laparotomy for endometrial cancer staging. Am J Obstet Gynecol. 2008; 198: 679. e1-10.

[50] Naik R, Jackson KS, Lopes A, Cross P, Henry JA. Laparoscopic assisted radical vaginal hysterectomy versus radical abdominal hysterectomy: A randomized phase II trial: Perioperative outcomes and surgicopathological measurements. BJOG. PubMed. 2010; 117: 746-51.
[51] Vermeij R, de Bock GH, Leffers N, Ten Hoor KA, Schulze U, Hollema $\mathrm{H}$ et al. Tumor-infiltrating cytotoxic $\mathrm{T}$ lymphocytes as independent prognostic factor in epithelial ovarian cancer with wilms tumor protein 1 overexpression. J Immunother. 2011; 34(6): 516-23.

[52] Kameliya Tsvetanova et al. The HIFU Technology during the Therapy of Uterine Myoma-First Attempts in Bulgaria. IJSR, Vol.5. P. 297.

[53] Kameliya Tsvetanova The influence of a Pneumoperitoneum on a Cardio-vascular System and Central Hemodynamics in the Medical Cases of Robotic and Laparoscopic Gynecological Surgeries. IJSR, Vol.5. P. 968.

[54] Rebeles S, Muntz H, Wieneke-Broghammer C, Vason E, McGonigle KF. Robot-assisted total laparoscopic hysterectomy in obese and morbidly obese women. J Robotic Surg. 2009; 3: 141-147.

[55] Reynolds RK, Advincula AP. Robot-assisted laparoscopic hysterectomy: Technique and initial experience. Am J Surg. 2006; 191: 555-560.

[56] Sert MB, Abeler VM, Dorum A et al. A new approach to treatment of early stage cervical carcinoma: Entire laparoscopic abdominal radical hysterectomy with bilateral pelvic lymphadenectomy without vaginal cuff closure - case reports. Eur J Gynecol Oncol. 2006; 27 : 531-533.

[57] Peeters F, Vaknin Z, Lau S et al. Technical modifications in the robotic assisted surgical approach for gynecologic operations. J Robotic Surg. 2010; 4: 253-257.

[58] Kameliya Tsvetanova et al. Comparative analysis of operative time, length of stay in ICU and estimated blood loss in robot-assisted and laparoscopic surgery. Scripta Scientifica Medica P. 41.

[59] Григор Горчев. „Лимфна дисекция при гинекологични тумори“ стр. 441-452 в книгата „Лимфна дисекция“, изд. ИК „Фотон и ИЯ“ ООД, ISBN - 978 -954 -756-071-0.

[60] Kameliya Tsvetanova. Multi-aspect Comparative Analysis of Some Perioperative Indicators in Laparoscopic and Robotic Surgery in Gynecologic Oncology. Disertation. P-230. 